\title{
LINGUISTIC FEATURES OF FILIPINO NETSPEAK IN ONLINE CONVERSATIONS
}

\author{
Justine Daphnie Salvacion ${ }^{1}$, Marilou Y. Limpot ${ }^{2}$ \\ ${ }^{1}$ Master of Arts in Filipino, Professional Schools, University of Mindanao, Davao City, Philippines, \\ ${ }^{2}$ Doctor of Education, Professor, University of Mindanao, Davao City, Philippines,
}

Article DOI: https://doi.org/10.36713/epra9380

DOI No: 10.36713/epra9380

\begin{abstract}
This study aimed to identify the linguistic features of Filipino Netspeak, the live experiences of students using it, as well as the educational implications of Netspeak. Hybrid method which involves a combination of discourse analysis and qualitative phenomenological were used. The corpus of the study was composed of a total of 314 Facebook posts, comments, and replies from a Facebook closed group created for seven (7) participants. On the other hand, other data were collected through an in-depth interview with the participants. Results revealed that the linguistic features of Filipino Netspeak include the following: compound, blend, acronym, abbreviation, unique orthography, unconventional use of punctuation marks, and use of emoji. Moreover, themes for students' experiences in using Filipino Netspeak were the succeeding: easy and comfortable use of shortened words, Netspeak as language of millennial, unintentional use of Netspeak in formal setting, words/emojis learned in online communication, conventional use of Netspeak in social media interaction, miscommunication in Netspeak, and the effect of Netspeak in orthography and grammar. Furthermore, results for educational implications were the following: Netspeak's popularity in the digital era for student's faster communication, Netspeak as a form of feedback and communication of teachers to students, Netspeak as a classroom strategy, and Netspeak's influence in the writing skills of students.
\end{abstract}

KEYWORDS: Netspeak, Filipino netspeak, discourse analysis, phenomenological research, Philippines

\section{INTRODUCTION}

The birth of internet has given a new way of communication, and new language which is popularly called now as 'Netspeak' (AbuSa'aleek, 2013; Dino \& Gustilo, 2018; Pei 2014; Wang \& Wang, 2017). Netspeak is the language used on the internet with characteristics such as abbreviation, initials, emoticons and shortened words (Baron, 2004). The language is seen as causing mishap as it is a non-formal language, and there could be difficulties in shifting from it to standard language (Dino \& Gustilo, 51; Turner et al., 2014). And although many find it to be convenient, some are still having miscommunications using it specially when two persons from different generations are involved (Dmytryuk \& Lysenko, 2020; Mustafa, Kandasamy \& Yasin, 2015). Moreover, studies revealed that students using Netspeak are having problems in formal writing (Jovanovic, 2013; Shaari \& Bataineh, 2015; Thangaraj \& Maniam, 2015; Tong, 2019).

In view in the facts stated, it is very important to be aware of the linguistic features of Netspeak to avoid convictions in using informal language (AbuSa'aleek, 2015; Dino \& Gustilo, 2018; Thangaraj \& Maniam, 2015; Ormazábal, 2017), as well as the experiences of those using, and the educational implications of it. In relation to this, the study of Netspeak will give a better understanding of this new language variety which will result to better internet communication (Wang \& Wang, 2017) of the people using it specially teachers and students who are the ones who use if often now due to the new mode of learning.

The study is anchored in Lev Vygotsky's socio-cultural theory which states that an individual's interaction in his/her environment has a huge impact in his/her language (De Grove, Cauberghe \& Looy, 2014; Nauman, 2016); which explains people learning Netspeak because of the contemporary time. Additionally, the linguistic features were based on Crystal's (2004) linguistic features.

At this time, studies must focus on languages that are useful (Fenianos, 2020). As such, there is a need to conduct the study because a lot have been research about this, but there has not been in the context of the Filipino language. Besides, 
studies conducted focuses only on the linguistic features, but not in the experiences of the people using it, and the educational implications. Lastly, there is a need for people to understand that using informal language in the internet is typical since it adheres to the changes happening, thus, it should not be deemed bad.

\section{OBJECTIVES}

The purpose of the study is to identify the linguistic features of Filipino Netspeak in online conversations, as well as to elucidate the live experiences of students using Filipino Netspeak, and its educational implications.

\section{METHODS}

This study employed a hybrid method which is composed of qualitative discourse analysis, and qualitative phenomenological. The qualitative discourse analysis was used to analyze the linguistic features of Filipino Netspeak, while the qualitative phenomenological was used in collecting the insights and experiences of the respondents in using Netspeak, and educational implications.

The corpus of the study was collected through a Facebook closed group created by the researcher for the seven (7) respondents. The respondents were active Facebook users taking up Bachelor of Secondary Education Major in Filipino to ensure they are fluent in the Filipino language, and that they can contribute to the educational implications of Netspeak. For one week, starting from July 3 to July 11, 2021, each of the respondents had create one or two posts a day, and had provide comments on the comment section which formed conversations. Combined posts, comments, and replies resulted to 314. After which, the researcher proceeded to the in-depth interview using the Key Informant Interview (KII) by means of validated questionnaire.

The collected corpus was then analyzed through discourse analysis to effectively discuss the linguistic features of a language (Nghipondoka, 2020; Syahfitri 2018). The researcher copied the statements from the Facebook closed group and were read individually. Each statement was analyzed, were given labels based on Crystal's linguistic features, and were encoded in a matrix. On the other hand, the data collected from the in-depth interview were first transcribed and proceeded to the reduction method which is the method of filtering and then remaining the important and useful information only (Namey, Guest, Thairu, Lucy \& Johnson, 2008). After that, it was submitted to the data analyst for the first and second cycle coding, and thematic analysis which is the method of identifying, analyzing, and interpreting themes in relation to the research questions (Braune \& Clarke, 2012), together with the matrix made for the linguistic features.

\section{RESULTS AND DISCUSSIONS}

Table 1

Some of the collected corpus from the Facebook closed group showing the linguistic features of Filipino Netspeak

\begin{tabular}{|c|c|}
\hline Linguistic Feature & Facebook comments/posts/replies \\
\hline \multirow{2}{*}{ Compound } & sanaol ikakasal \\
\hline & sayang Mmr ko lodicakes \\
\hline Blend & awit iiiiiiiiidoooolooooooo \\
\hline \multirow{9}{*}{ Abbreviation } & Lumalaban pa rin mads \\
\hline & Shout out sa admin wag kanang mag puyat wala ka namang ka chat HAHAHAHAA \\
\hline & tinatanong mo ata sarili mo? \\
\hline & ANGKOL BOBBY KAYA TO $\Theta$ \\
\hline & Wla pang grades. \\
\hline & umuwi ka kasi tol HAHAHA \\
\hline & di ko alam \\
\hline & apakakyut HAHAHHAHA \\
\hline & $\begin{array}{l}\text { Wala akong akng pakialam sa search2 na yan mas kailangan kong pansinin ay ang } \\
\text { research HAHAHAHAHA }\end{array}$ \\
\hline \multirow{2}{*}{ Acronym } & TAPOS NA DIN SA RIZAL SKL $\Theta \Theta \Theta$ \\
\hline & SML \\
\hline \multirow{5}{*}{ Unique Orthography } & depende iiiiiiiiidoooolooooooo \\
\hline & cge po НAHAHA \\
\hline & MAGANDANG GABI KABAYAN HAHAHAHAHAHA \\
\hline & Magbibirthday yarn? $\Theta$ \\
\hline & tubig2 lang \\
\hline
\end{tabular}




\begin{tabular}{|c|l|}
\hline \multirow{4}{*}{$\begin{array}{c}\text { Unconventional use } \\
\text { of punctuation marks }\end{array}$} & GOOO KAAGAPAY PARTYLIST LABAN JAPAN LANG TAYO!!! \\
\cline { 2 - 3 } & salamat sa inyo.. vote KAAGAPAY PARTY \\
\cline { 2 - 3 } & Sana all yarn?? \\
\cline { 2 - 2 } & Shai remember??? Birthday mo bukas,! \\
\cline { 2 - 2 } Emoji & E** is life 20 \\
\hline & mag pa enroll pa pala 9 \\
\hline & maraming salamat \\
\hline & walang personalan 900 \\
\hline & $\begin{array}{l}\text { SA HUNYO SINGKO, GUMISING NG MAAGA. HUWAG KALIMUTAN ITO ANG } \\
\text { ARAW NG PILIAN }\end{array}$ \\
\hline & pabuhat mga lods \\
\hline & ML ay iwasan, transkripsyon ay pagtuonan! \\
\hline & MAGANDANG GABI ALL \\
\hline
\end{tabular}

\section{Linguistic Features of Filipino Netspeak}

As shown in the table above, the linguistic features of Filipino Netspeak are as follows based on the linguistic features of Crystal (2004): (1) compound, (2) blend, (3) abbreviation, (4) acronym, (5) unique orthography, (6) unconventional use of punctuation marks, and (6) emoji.

\section{Compound}

Compounding is the combination of two words to form another word (Dino \& Gustilo, 2018; Yan-hong, 2013). This is one characteristics of Netspeak designed for its creativity and uniqueness. For Filipino Netspeak compound, only two words were seen from the data collected. The words 'sanaol' from the two words 'sana' and 'all', and 'lodicakes' from the words 'lodi' and 'cakes'.

Blend

As for blend, only one word was seen, the word 'awit' from the expression 'aw' and 'it' from the word 'sakit'. Blending is the combination of a word and a part of a word to form another word (Sun 100; Yan-hong 800). A lot of blends can be found in Netspeak such as 'Gootube' from the words 'Google' and 'Youtube' (Yeo \& Ting, 2017).

\section{Abbreviation}

To save time in online communication, one way to do is abbreviate the words (AbuSa'aleek, 2015; Averianova, 2012) which is one feature of Filipino Netspeak. Some of the shortened words are formed by deleting a letter like 'wla' from 'wala', and 'akng' from 'akong', or a syllable like 'di' from the word 'hindi'.

\section{Acronyms}

Just like abbreviation, acronyms are also used to shorten words for faster online communication (Averianova, 2012; Jovanovic, 2013; Sun, 2010). Two of Filipino Netspeak acronyms are 'SKL' from 'Share Ko Lang', and 'SML' from 'Share Mo Lang'.

\section{Unique Orthography}

One of the visible linguistic features of Netspeak is its unique orthography (AbuSa'aleek, 2015; Fenianos, 2020; Dorda, 2010; Fiorentini, 2013; Kadir, Maros, \& Hamid, 2012). Based on the collected data, vowel lengthening, 'idolo' to 'iiiiiiiidoooolooooooo', replacing a syllable using a letter like 'cge' from 'sige', using number to repeat a word like 'tubig2', and adding a letter to a word like 'yan' to 'yarn' can be seen.

\section{Unconventional Use of Punctuation Marks}

As for unconventional use of punctuation marks, data shows there is repetition of punctuation marks or a combination of two, and the use of asterisk to hide letters. Cvjetkovic (2010) stated that repeating of punctuations and other styles are being used to pertain different emotions.

\section{Emoji/Emoticons}

Emotions cannot be seen in online texting, that is why emojis are used to intensify messages (Kadir, Maros, \& Hamid, 2012). From the collected data, the most used were the different smileys, heart, and other emojis to add to the meaning of the messages they want to convey.

Table 2

The formulated theme and central idea on the experiences of students in using Netspeak.

\begin{tabular}{|l|l|l|}
\hline \multicolumn{1}{|c|}{ Themes } & \multicolumn{1}{c|}{ Central Idea } \\
\hline $\begin{array}{l}\text { Easy and conventional use of } \\
\text { shortened words }\end{array}$ & - $\begin{array}{l}\text { Easier communication to classmates through the use of } \\
\text { shortened words } \\
\text { Students use Netspeak when they have questions about their } \\
\text { subject. } \\
\text { Conventional to use since it is easier to type messages and read }\end{array}$ \\
\hline Netspeak as language of millennial & - $\begin{array}{l}\text { Millennials use Netspeak in talking about online games and } \\
\text { trending issues }\end{array}$ \\
\hline
\end{tabular}




\begin{tabular}{|c|c|}
\hline & - Netspeak is used in chatting friends online \\
\hline $\begin{array}{l}\text { Unintentional use of Netspeak in } \\
\text { formal setting }\end{array}$ & $\begin{array}{l}\text { - Sometimes it is unintentionally used in formal conversations } \\
\text { - Sometimes it is unintentionally used in writing essays and } \\
\text { articles on tasks, and formal writing } \\
\text { - Sometimes it is unintentionally used in oral recitations } \\
\end{array}$ \\
\hline $\begin{array}{l}\text { Words/emojis learned in online } \\
\text { communication }\end{array}$ & $\begin{array}{ll}\text { - } & \text { Words/emojis used online are adapted } \\
\text { - } & \text { Easier to deliver messages since many words are learned online } \\
\text { - } & \text { Emojis are used to intensify messages }\end{array}$ \\
\hline $\begin{array}{l}\text { Conventional use of Netspeak in } \\
\text { social media interaction }\end{array}$ & $\begin{array}{l}\text { - Netspeak is used in commenting and posting in social media } \\
\text { - Netspeak is used in funny comments in Facebook }\end{array}$ \\
\hline Miscommunication in Netspeak & $\begin{array}{l}\text { - Old people are having a hard time understanding a message } \\
\text { using Netspeak } \\
\text { - Sometimes there can be miscommunication because one cannot } \\
\text { understand Netspeak }\end{array}$ \\
\hline $\begin{array}{l}\text { Effect of Netspeak in orthography } \\
\text { and grammar }\end{array}$ & $\begin{array}{l}\text { - Sometimes rules in grammar are forgotten } \\
\text { - } \quad \text { Sometimes correct spelling of words is forgotten } \\
\end{array}$ \\
\hline
\end{tabular}

Experiences of Students in Using Netspeak

From the data collected, seven (7) themes emerged:

(1) Easy and conventional use of shortened words,

(2) Netspeak as language of millennial, (3) Unintentional use of Netspeak in formal setting, (4) Words/emojis learned in online communication, (5) Conventional use of Netspeak in social media interaction, (6) Miscommunication in Netspeak, and (7) Effect of Netspeak in orthography and grammar. Easy and conventional use of shortened words

As shown in the table above, Netspeak is used since communication on the internet has limitations. That is why most of the time people use shortened words to send messages in a short period of time (Sun, 2010; Yan-hong, 2013). Respondents have said they use Netspeak in shortcut of words to immediately deliver a message.

Netspeak as language of millennial

As most of the people using Netspeak are ages 15-24 (Gustillo \& Dino, 2017), using the language is really a thing of the millennials, particularly that they are into this generation of commenting and posting in social media (Monderin \& Go, 2021; Shaari \& Bataineh, 2015).

Unintentional use of Netspeak in formal setting

Respondents have used Netspeak almost everyday in their online communication, that is why there is a big possibility that they can use it in the formal setting. Thangaraj and Maniam (2015) have stated that Netspeak has really a negative effect in students. According to them, students who use Netspeak most of the time most probably use it in formal writing as well.

Words/emojis learned in online communication Socio-cultural theory highlights that an individuals' language is learned through his/her interaction with the environment (De Grove, Cauberghe \& Looy, 2014; Nauman, 2016). That is why students learn words and emojis used through their interaction in online communication. Additionally, as a feature of Netspeak, emojis are also used to really convey the meaning of the message (Crystal, 2004; Fenianos, 2020; Nghipondoka, 2020; Pei, 2014).

Conventional use of Netspeak in social media interaction

Social media has become a way for a language to adapt in its needs (Monderin \& Go, 2021), most specially the use of Facebook where different communication have emerged (Maňáková, 2017). As a result, Netspeak has been used for conventional messaging (Para, 2016).

\section{Miscommunication in Netspeak}

Dmytryuk and Lysenko (2020) and Mustafa, Kandasamy and Yasin (2015) have found out that differences in language often results to miscommunication most specially when two different generations are involved. Because of the internet slangs, there are times when it cannot be understood by those who do not use it (Dmytryuk \& Lysenko, 2020).

Effect of Netspeak in orthography and grammar

Netspeak is seen as a playful language, therefore a non-standard language (Herring, 2012). It is also described as a language that is very different, inevitably, there is a high possibility that students or anyone using it would bring it in the class and would forget the correct spelling of words or construct sentences with incorrect grammar (Shaari \& Bataineh, 2015). 
Table 3

The formulated theme and central idea on the educational implications of Netspeak.

\begin{tabular}{|c|c|}
\hline Themes & Central Idea \\
\hline $\begin{array}{l}\text { Netspeak's popularity in the digital } \\
\text { era for student's faster } \\
\text { communication }\end{array}$ & $\begin{array}{l}\text { - Students can communicate faster in his/her classmates when } \\
\text { using Netspeak } \\
\text { - Netspeak is easier and more convenient to use in online } \\
\text { communication than formal language } \\
\text { - Netspeak is used by students in asking their teachers }\end{array}$ \\
\hline $\begin{array}{l}\text { Netspeak as a form of feedback and } \\
\text { communication of teachers to } \\
\text { students }\end{array}$ & $\begin{array}{ll}\text { - } & \text { Emojis are used by teachers in giving feedbacks } \\
\text { - } & \text { Netspeak is sometimes used in checking outputs }\end{array}$ \\
\hline Netspeak as a classroom strategy & $\begin{array}{l}\text { - Netspeak is used as an activity in the class } \\
\text { - Netspeak is used as a strategy not only in delivering the lesson } \\
\text { but understanding the lesson as well. }\end{array}$ \\
\hline $\begin{array}{l}\text { Netspeak's influence in the writing } \\
\text { skills of students }\end{array}$ & $\begin{array}{l}\text { - Writing using correct spelling is affected. } \\
\text { - It is unavoidable sometimes that words in writing activities are } \\
\text { shortened } \\
\text { - Writing and grammar are affected. }\end{array}$ \\
\hline
\end{tabular}

Educational Implications of Netspeak

As cited in the responses of the participants, four (4) themes have transpired which are the following: (1) Netspeak's popularity in the digital era for student's faster communication, (2) Netspeak as a form of feedback and communication of teachers to students, (3) Netspeak as a classroom strategy, and (4) Netspeak's influence in the writing skills of students.

\section{Netspeak's popularity in the digital era for student's faster communication}

Social media sites, and the language used in it can be used by teachers and students in their communication specially in this time of pandemic. Additionally, tasks and assignments may be discussed using it (Touati \& Moumen, 2019). Studies have also found out that when students use the different social media sites and the language in it, they will have a more comfortable conversation where they can share their thoughts effectively (Begaga, n.d).

\section{Netspeak as a form of feedback and communication of teachers to students}

Netspeak, particularly emoticons/emojis were seen as an effective way for online feedbacking of tasks; in addition, teachers must use it for students to feel the teacher, and the emotions upon checking their works (Dunlap et al., 2014). Moreover, a study of Grieve, Moffitt and Padgett (2019) have found out that students would appreciate teachers using emojis more than those who are not.

\section{Netspeak as a classroom strategy}

The vast formation of language found in Netspeak can be a good motivation in different topics specially in language lessons. Furthermore, teachers can use examples of statements written in Netspeak for them to analyze the different features and characteristics and realize how dynamic a language could be (Dino \& Gustilo, 2018).

\section{Netspeak's influence in the writing skills of students}

A study conducted by Rosen, Chang, Erwin, Carrier, \& (2010) have found out that Netspeak has been a reason for students' poor writing. The like is also agreed by Shaari and Bataieh (2015) when they said that incorrect spelling which is seen as normal in the online communication affects students' writing. Students' work using Netspeak have been found to have distorted morphological and syntactical use of language. As a consequence, it is really a must for students to have limitations in using the language, and that they are constantly reminded of the proper use of it.

\section{CONCLUSIONS}

Netspeak is a language used by people communicating through the internet; and based on the results of the study, its linguistic features are used for a convenient and effective interaction, and to regulate the limitations of online communication. However, students as well as teachers must have an awareness of when to use Netspeak properly and when to use the formal and informal language since it is inevitable for it to be used in the formal setting specifically inside the classroom. Nonetheless, Netspeak has proven that language is dynamic, it is timely, and is adapting to the needs of the present; and when used correctly, it can be a useful and productive language. 


\section{REFERENCES}

1. AbuSa'aleek, A. O. (2013). Linguistic dimensions of initialisms used in electronic communication. Studies in Literature and Language, 6(3), 7-13.

2. AbuSa'aleek, A. O. (2015). Internet linguistics: A linguistic analysis of electronic discourse as a new variety of language. International Journal of English Linguistics, 5(1), 135.

3. Averianova, I. (2012). The language of electronic communication and its implications for TEFL. Procedia-Social and behavioral sciences, 34, 14-19.

4. Baron, N. S. (2004). See you online: Gender issues in college student use of instant messaging. Journal of language and social psychology, 23(4), 397-423.

5. BEGAGA, D. The Effects of Chat Language on Student's Academic Writing The Case of First Year Master Students of English at Biskra University A Dissertation submitted to the Department of Foreign Languages in partial fulfilment of the requirements for the Master's Degree in English: Sciences of Language (Doctoral dissertation).

6. Braun, V., \& Clarke, V. (2012). Thematic analysis.

7. Crystal, D. (2004). Language and the internet. Madrid: Cambridge university press.

8. Cvjetkovic, S. (2010). Computer-mediated communication: A study of language variation on internet chat. rapport $n r .:$ SPL kandidatuppsats $i$ engelska SPL 2010-005.

9. De Grove, F., Cauberghe, V., \& Van Looy, J. (2014). In pursuit of play: Toward a social cognitive understanding of determinants of digital play. Communication Theory, 24(2), 205-223.

10. Dezhi, W. A. N. G., \& Shasha, W. A. N. G. (2017). Research on features of chatroom netspeak from a stylistic view. Studies in Literature and Language, 15(1), 43-46.

11. Dino, C. M., \& Gustilo, L. (2018). FB Digitalking: Standard, Non-Standard, or Hybrid?. Advanced Science Letters, 24(11), 8328-8331.

12. Dmytryuk, S. V., \& Lysenko, V. V. (2020). Internet slang. In Інноватика в освіті, науці та бізнесі: виклики та можливості. Київський національний університет технологій та дизайну.

13. Dorda, S. V. (2010). Netspeak-is it the future? (Doctoral dissertation, Kyiv National Linguistic University).

14. Dunlap, J. C., \& Lowenthal, P. R. (2014). The power of presence: Our quest for the right mix of social presence in online courses. Real life distance education: Case studies in practice, 41-66.

15. Fenianos, C. F. (2020). Internet Language: An Investigation into the Features of Textisms in an ESL/EFL Context. Journal of Arts and Humanities, 9(2), 63-74.

16. Fiorentini, I. (2013). Zomg! Dis Iz A New Language”: The Case Of Lolspeak. Selected Papers from Sociolinguistics Summer School, 4, 90-108.

17. Grieve, R., Moffitt, R. L., \& Padgett, C. R. (2019). Student perceptions of marker personality and intelligence: The effect of emoticons in online assignment feedback. Learning and Individual Differences, 69, 232-238.

18. Gustilo, L. E., \& Dino, C. M. (2017). Old Speak or Young Speak: An Analysis of Netspeak Features in
Filipino Netspeak. Advanced Science Letters, 23(2), 1099-1103.

19. Herring, S. C. (2012). Grammar and electronic communication. The encyclopedia of applied linguistics, 1-9.

20. Jovanovic, D. (2013). A qualitative study of the use of netspeak in English language classroom: implementation of netspeak in high school and university language teaching (Master's thesis, fi= Lapin yliopisto $\mid$ en $=$ University of Lapland $\mid$ ).

21. Kadir, Z. A., Maros, M., \& Hamid, B. A. (2012). Linguistic features in the online discussion forums. International Journal of Social Science and Humanity, 2(3), 276.

22. Maňáková, J. (2017). [NEOBHÁJENO]
[NG Morphosyntactic Features of Facebook Communication.

23. Monderin, C., \& Go, M. B. (2021). Emerging Netspeak Word Choices in Social Media on Filipino Pop Culture. International Journal of Linguistics, Literature and Translation, 4(6), 49-61.

24. Mustafa, S. Z. B., Kandasamy, M., \& Yasin, M. S. M. (2015). An analysis of word formation process in everyday communication on Facebook. International Journal of Education and Research, 3(6), 261-274.

25. Namey, E., Guest, G., Thairu, L., \& Johnson, L. (2008). Data reduction techniques for large qualitative data sets. Handbook for team-based qualitative research, 2(1), 137-161.

26. Nauman, S. (2016). EVALUATING NETSPEAK THROUGH VYGOTSKY'S SOCIO-CULTURAL THEORY AND ITS EFFECTS ON PAKISTANI BUSINESS SCHOOL STUDENTS'STANDARD ENGLISH. Pakistan Business Review, 18(1), 232-246.

27. Nghipondoka, T. N. (2020). Exploring linguistic" creativity" on social media: A case of selected posts by Namibians on Facebook, Twitter and WhatsApp (Doctoral dissertation, University of Namibia).

28. Ormazábal, M. A. S. (2017). Text Messaging and its Impact on Written Standard English. VERBEIA. Revista de Estudios Filológicos. Journal of English and Spanish Studies, (2), 116-138.

29. Para, I. (2016). "Online communication-Netspeak". Language in digital era challenges and perspectives. De Gruyter Open Poland, 189-200

30. Pei, B. (2014). Study on lexical features of English netsp eak from semiotic perspective. Journal of Chemical and Pharmaceutical Research, 6(4), 96-100.

31. Rosen, L. D., Chang, J., Erwin, L., Carrier, L. M., \& Cheever, N. A. (2010). The relationship between "textisms" and formal and informal writing among young adults. Communication Research, 37(3), 420440.

32. Shaari, A. H., \& Bataineh, K. B. (2015). Netspeak and a Breach of Formality: Informalization and Fossilization of Errors in Writing among ESL and EFL Learners. International Journal for Cross-Disciplinary Subjects in Education (IJCDSE), 6(2).

33. Sun, H. M. (2010). A study of the features of internet english from the linguistic perspective. Studies in Literature and Language, 1(7), 98-103.

34. SYAHFITRI, A. (2018). The Analysis of netspeak used in facebook. 
35. Thangaraj, S. R., \& Maniam, M. (2015). The Influence of Netspeak on students' writing. Journal of Education and Learning, 9(1), 45-52.

36. Tong, L. (2019, May). An Analysis on the Forms and Characteristics of English Netspeak. In 2019 4th International Conference on Social Sciences and Economic Development (ICSSED 2019) (pp. 468-471). Atlantis Press.

37. TOUATI, M. N. M., \& MOUMEN, M. F. Z. (2019). The Effect of Social Media Language on EFL Learners' Academic Writing Performance. Case of Master OneLinguistics Students at M'sila University (Doctoral dissertation)

38. Turner, K. H., Abrams, S. S., Katíc, E., \& Donovan, M. J. (2014). Demystifying digitalk: The what and why of the language teens use in digital writing. Journal of Literacy Research, 46(2), 157-193.

39. Yan-hong, M. (2013). A Primary Study on Netspeak $\square$. US-China Education Review, 797.

40. Yeo, D., \& Ting, S. (2017). Netspeak features in Facebook communication of Malaysian university students. Journal of Advanced Research in Social and Behavioural Sciences, 6(1), 81-90. 